\title{
Associate Academic Degree Completion
}

National Cancer Institute

\section{Source}

National Cancer Institute. Associate Academic Degree Completion. NCI Thesaurus. Code C67140.

Indicates that a person has received a degree from a 2 year college program. 